\title{
PENGARUH MOTIVASI DAN MODAL USAHA TERHADAP MINAT BERWIRAUSAHA DI PASAR KOMPLEK MMTC KOTA MEDAN
}

\author{
Nalom Siagian', Darma Manalu² \\ Fakultas Ilmu Sosial dan Politik, Universitas HKBP Nommensen \\ nalom.siagian@uhn.ac.id
}

\begin{abstract}
ABSTRAK : Penelitian ini bertujuan untuk mengetahui pengaruh motivasi dan modal usaha terhadap minat berwirausaha melalui penelitian dengan pendekatan kuantitatif. Objek penelitian adalah wirausahawan di Pasar Komplek MMTC, Kota Medan yang berjumlah 100 wirausahawan, menggunakan data primer dan sekunder melalui kuessioner skala liskert. Data penelitian ini diolah melalui uji validitas, uji reliabilitas, regresi berganda serta uji hipotesis melalui uji parsial dan uji simultan. Berdasarkan hasil uji validitas dan uji reliabilitas, variable Motivasi ( $\left.\mathrm{X}_{1}\right)$, Modal usaha $\left(\mathrm{X}_{2}\right)$ dan Minat Berwirausaha $(\mathrm{Y})$ dapat disimpulkan valid dan reabel berdasarkan kriteria pengujian rhitung $>$ rtabel dan combrach alpha $>0,6$ dari semua indikator masing-masing variabel. Berdasarkan kriteria pengujian $t_{\text {tabel }}$, nilai t hitung yang dihasilkan pada variabel Motivasi $\left(\mathrm{X}_{1}\right)=$ $6,264>\mathrm{t}$ tabel $(\alpha=0,05 / 2 ; n-k-1)=1,985$. Berarti variabel Motivasi $\left(\mathrm{X}_{1}\right)$ berpengaruh positif terhadap Minat berwirausaha. Berdasarkan kriteria pengujian $\mathrm{t}_{\text {tabel }}$, nilai $\mathrm{t}$ hitung yang dihasilkan pada variabel Modal Usaha $\left(\mathrm{X}_{2}\right)=-0,288<\mathrm{t}$ tabel $(\alpha=0,05 / 2 ; \mathrm{n}-\mathrm{k}-1)=1,985$. Hal ini berarti variabel modal usaha $\left(\mathrm{X}_{2}\right)$ berpengaruh negatif terhadap Minat berwirausaha. Berdasarkan Tabel 4.18 didapat nilai $\mathrm{F}$ hitung sebesar 20,802 $>\mathrm{F}$ tabel $(\alpha=\mathrm{k} ; \mathrm{n}-\mathrm{k})=2,70$ dengan $\mathrm{F}$ sig. 0,000 dimana F sig. 0,000 < 0,05 maka H0 ditolak. Dapat diartikan bahwa motivasi $\left(\mathrm{X}_{1}\right)$ dan modal usaha $\left(\mathrm{X}_{2}\right)$ beperngaruh positif dan signifikan secara simultan terhadap minat berwirausaha (Y).
\end{abstract}

\section{Kata Kunci : Motivasi, Modal Usaha dan Minat Berwirausaha}

\begin{abstract}
This study aims to determine the effect of motivation and working capital on interest in entrepreneurship through research with a quantitative approach. The object of the research is entrepreneurs in the MMTC Complex Market, Medan City, totaling 100 entrepreneurs, using primary and secondary data through a liskert scale questionnaire. The research data was processed through validity testing, reliability testing, multiple regression and hypothesis testing through partial and simultaneous tests.Based on the results of the validity and reliability tests, the variables Motivation $\left(X_{1}\right)$, Business capital $\left(X_{2}\right)$ and Entrepreneurial Interest $(Y)$ can be concluded as valid and reliable based on the test criteria rcount rtable and combrach alpha 0.6 of all indicators of each variable. Based on the ttable test criteria, the calculated $t$ value for the Motivation variable $\left(X_{1}\right)=6.264>t$ table $(\alpha=0.05 / 2 ; n-k-1)=1.985$. It means that the motivation variable $\left(X_{1}\right)$ has a positive effect on entrepreneurial interest. Based on the t-table test criteria, the calculated $t$-value generated on the variable Business Capital $\left(X_{2}\right)=-0.288<t$ table $(\alpha=0.05 / 2 ; n-k-1)=1.985$. This means that the working capital variable $\left(X_{2}\right)$ has a negative effect on entrepreneurial interest. Based on Table 4.18, the calculated $F$ value is $20.802>F$ table $(\alpha=k ; n-k)=2.70$ with F sig. 0.000 where $F$ sig. $0.000<0.05$ then HO is rejected. It can be interpreted that motivation $\left(X_{1}\right)$ and working capital $\left(X_{2}\right)$ have a positive and significant effect simultaneously on interest in entrepreneurship $(Y)$.
\end{abstract}

Keywords: Motivation, Business Capital and Interest in Entrepreneurship

\section{PENDAHULUAN}

Dewasa ini masyarakat kesulitan dalam menemukan lapangan pekerjaan. Banyak sarjana yang hanya menjadi pengangguran, Akibatnya pendidikan yang dulunya begitu diagung-agungkan justru terlihat percuma. Banyaknya orang dengan gelar sarjana dan keinginan untuk dapat memenuhi kebutuhan sehariharinya menjadi faktor yang memicu orang-orang untuk mencari pekerjaan. Sayangnya, persaingan yang begitu ketat dalam seleksi pekerjaan dan banyaknya 
orang yang bersaing dalam mencari pekerjaan membuat banyak cendekiawan muda yang menjadi pengangguran.

Hal ini menunjukkan semakin pentingnya dunia entrepreneur di dalam perekonomian suatu negara. Pembangunan akan lebih berhasil jika ditunjang oleh para entrepreneur yang dapat membuka lapangan kerja karena kemampuan pemerintah sangat terbatas. Pemerintah tidak akan mampu menggarap semua pembangunan karena sangat banyak membutuhkan anggaran belanja, personalia, dan pengawasan. Sehingga, lapangan yang mampu pemerintah siapkan pun sangatlah terbatas dan sulit untuk memenuhi seluruh masyarakat di Indonesia.

Seorang wirausahawan adalah seorang yang memiliki keahlian untuk menjual, mulai dari menawarkan ide hingga komoditas baik berupa produk atau jasa. Sebagai pelaku bisnis, wirausahawan harus mengetahui dengan baik manajemen penjualan, gaya dan fungsi manajemen. Untuk berhasil, ia harus mampu berkomunikasi dan menguasai beberapa elemen kecakapan manajerial, serta mengetahui teknik menjual yang strategis mulai dari pengetahuan tentang produk, ciri khas produk dan daya saing produk terhadap produk sejenis. Membuka usaha bukanlah perkara yang mudah. Ada orang yang membuka usaha karena tidak ada pilihan lain selain membuka usaha sendiri. Ada orang yang membuka usaha sendiri karena pendidikan rendah yang membuat sulit mencari pekerjaan. Ada juga orang yang terpaksa membuka usaha sendiri karena terkena PHK dari perusahaan tempatnya bekerja. Sedangkan ada orang yang membuka usaha sendiri karena lebih senang memilih usaha sendiri daripada bekerja pada orang lain.

Membentuk budaya kewirausahaan dalam lingkungan masyarakat sangatlah penting. Budaya kewirausahaan sendiri biasanya tumbuh secara alami dalam suatu keluarga atau kelompok masyarakat Indonesia. Terlebih lagi melihat situasi dan kondisi saat ini dimana banyak tenaga kerja yang telah kehilangan pekerjaannya dikarenakan pandemi Virus Corona yang melanda negeri ini, bahkan seluruh negara di dunia ini merasakan akibatnya. Sehingga peran seorang wirausahawan sangat penting untuk membantu menopang perekonomian bangsa ini. Namun, walaupun budaya ini mampu bertahan semua itu tidak ada gunanya bila tidak ada motivasi yang mendorong keinginan masyarakat untuk berwirausaha.

Kebebasan dalam bekerja merupakan sebuah model kerja dimana seseorang melakukan pekerjaan sedikit tetapi memperoleh hasil yang besar. Berangkat kerja tanpa terikat pada aturan atau jam kerja formal. Keberhasilan diri yang dicapai merupakan pencapaian tujuan kerja yang diharapkan, yang meliputi kepuasan dalam bekerja dan kenyamanan kerja. Toleransi akan resiko, merupakan seberapa besar kemampuan dan kreativitas seseorang dalam menyelesaikan besar kecilnya suatu resiko yang diambil untuk mendapatkan penghasilan yang diharapkan. Semakin besar seseorang pada kemampuan diri sendiri, semakin besar pula keyakinannya terhadap kesanggupan mendapatkan hasil dari keputusannya dan semakin besar keyakinannya untuk mencoba apa yang dilihat orang lain beresiko. Penelitian ini dilakukan karena melihat peran entrepreneur sangat dibutuhkan terlebih saat ini, dimana pencari kerja lebih banyak daripada penyedia kerja. Apalagi setelah melihat kondisi yang terjadi saat ini, dimana terjadi PHK di berbagai perusahaan yang mengakibatkan banyak tenaga kerja yang telah kehilangan pekerjaannya akibat pandemi Virus Corona yang terjadi, bukan hanya di Indonesia saja tetapi juga di negara-negara lain dan telah memberi dampak yang sangat besar salah satunya terhadap bidang perekonomian. Oleh karena itu, 
peran wirausahawan diharapkan dapat mengurangi banyaknya pengangguran yang terjadi di negara ini.

Berdasarkan latar belakang di atas, maka yang menjadi masalah dalam penelitian ini adalah untuk menganalisis kemampuan motivasi dan modal usaha untuk mempengaruhi minat masyarakat untuk berwirausaha yang dirumuskan sebagai berikut : (1) Apakah Motivasi berpengaruh positif dan signifikan terhadap minat masyarakat berwirausaha? (2) Apakah Modal Usaha berpengaruh positif dan signifikan terhadap minat masyarakat berwirausaha? (3) Apakah Motivasi dan Modal Usaha berpengaruh positif dan signifikan terhadap minat masyarakat berwirausaha?

Motivasi merupakan proses psikologis yang mendasar dan merupakan salah satu unsur yang dapat menjelaskan perilaku seseorang. Motivasi adalah kemauan untuk berbuat sesuatu sedangkan motif adalah kebutuhan, keinginan atau dorongan. Menjadi seorang entrepreneur sering dipandang sebagai pilihan karir yang menantang, dimana seseorang menghadapi kehidupan sehari-hari dalam situasi kerja yang penuh dengan rintangan kerja, kegagalan, ketidakpastian, dan frustasi yang dihubungkan dengan proses pembentukan usaha yang dilakukan. Motivasi usaha merupakan salah satu pendorong tumbuh kembangnya jiwa wirausaha seseorang. Kesuksesan seseorang seringkali disertai dengan motivasinya yang kuat dalam menjalakan setiap usaha yang dijalaninya.

Pengertian motivasi menurut Edwin B Flippo dalam buku Hasibuan (2013.143) "Motivasi adalah suatu keahlian, dalam mengarahkan pegawai dan organisasi agar mau bekerja secara berhasil, sehingga keinginan para pegawai dan tujuan organisasi sekaligus tercapai" Hasibuan dalam buku Sutrisno (2009. 110) mengemukakan, "Motivasi adalah bagaimana cara mendorong gairah kerja bawahan, agar mereka mau bekerja keras dengan memberikan semua kemauan dan keterampilan untuk mewujudkan tujuan perusahaan". Sedangkan menurut Fillmore H. Stanford dalam buku Mangkunegara (2001. 93) "Motivasi sebagai suatu kondisi menggerakaan manusia ke arah suatu tujuan tertentu. Dari beberapa pengertian yang dikemukan oleh para ahli di atas, maka dapat disimpulkan bahwa motivasi adalah suatu usaha ataupun tindakan untuk mendorong setiap orang maupun karyawan agar mereka bekerja semaksimal mungkin dan mengeluarkan segala potensi yang dimilikinya untuk mewujudkan tujuan perusahaan.

Berangkat dari kenyataan bahwa pemahaman tentang berbagai kebutuhan manusia makin mendalam, penyempurnaan dan koreksi dirasakan bukan hanya tepat, akan tetapi juga memang diperlukan karena pengalaman menunjukkan bahwa usaha pemuasan berbagai kebutuhan manusia berlangsung secara simultan. Artinya, sambil memuaskan kebutuhan fisik, seseorang pada waktu yang bersamaan ingin menikmati rasa aman, merasa dihargai, memerlukan teman serta ingin berkembang. Dengan adanya motivasi, kita mempunyai dorongan untuk berbuat, melakukan sesuatu yang diinginkan.

Berdasarkan semua teori tersebut dapat disimpulkan bahwa motivasi adalah semua kekuatan yang memberi energy, daya, arah, dan dorongan untuk melakukan atau tidak melakukan kegiatan-kegiatan tertentu guna mencapai tujuan, baik pemenuhan kebutuhan atau pencapaian kepuasan.

Maslow dalam teorinya mengetengahkan tingkatan (hierarchi) kebutuhan, yang berbeda kekuatannya dalam memotivasi seseorang melakukan suatu kegiatan.dengan kata lain kebutuhan bersifat bertingkat, yang secara berurutan berbeda kekuatannya dalam memotivasi suatu kegiatan, termasuk juga yang 
disebut bekerja. Maslow mengemukakan bahwa kebutuhan manusia itu dapat diklasifikasikan ke dalam lima hierarkhi kebutuhan, sebagai berikut :

a. Kebutuhan fisik

Motivasi paling dasar adalah bukanlah uang, tapi bagi manusia kebutuhan paling dasarnya adalah kebutuhan adalah kebutuhan untuk bertahan hidup.

b. Kebutuhan rasa aman

Setelah kebutuhan tingkat dasar terpenuhi, maka eseorang berusaha memenuhi kebutuhannya yang kebih tinggi, yaitu kebutuhan akan raa aman dan keelamatan.

c. Kebutuhan sosial Seseorang membutuhkan pertemanan, keluarga dan keintiman. Hal ini dikarenakan manusia merupakan makhluk sosial.

d. Kebutuhan pengakuan

Kebutuhan akan pengakuan merupakan tahap keempat dalam hierarki kebutuhan Maslow.

e. Kebutuhan aktualisasi diri

Dalam tahap aktualisasi diri ini akhirnya mengenalai dirinya dan berusaha hidup, memegang nilai-nilai, memecahkan masalah, menilai sesuatu, mengolah data informasi berdasarkan apa yang dia yakini. Anwar P. Mangkunegara (2001. 95)

Berdasarkan teori dan indikator motivasi diatas, maka yang menjadi indikator variabel motivasi dalam penelitian ini adalah :

1. Kebutuhan fisiologis, ditunjukkan dengan :kebutuhan untuk makan, minum, perlindungan fisik. Kebutuhan ini merupakan kebutuhan paling dasar.

2. Kebutuhan rasa aman, ditunjukkan dengan : kebutuhan akan perlindungan dari ancaman, bahaya, pertentangan dan lingkungan hidup.

3. Kebutuhan untuk merasa memiliki, ditunjukkan dengan : untuk diterima dalam kelompok, berinteraksi dan kebutuhan untuk mencintai dan dicintai.

4. Kebutuhan akan harga diri, ditunjukkan dengan : kebutuhan untuk dihormati dan dihargai oleh karyawan lain dan pimpinan terhadap prestasi kerja.

Modal usaha dalam Kamus Besar Bahasa Indonesia adalah uang yang dipakai sebagai pokok (induk) untuk berdagang, melepas uang dan sebgainya harta benda (uang, barang dan sebagainya) yang dapat dipergunakan untuk menghasilkan sesuatu yang menambah kekayaan. Kartika Putri, Dkk ( hal 4). Modal dalam pengertian ini dapat diinterprestasikan sebagai sejumlah uang dan barang yang digunakan dalam menjalankan kegiatan-kegiatan usaha.

Modal menurut Sugiarto adalah segala nilai sesuatu aktiva yang dimiliki oleh perusahaan dan yang digunakan, untuk menghasilkan pendapatan atau laba. Modal terbagi menjadi dua bagian diantaranya:

1. Modal internal, adalah segala sesuatu yang ditanamkan oelh perusahaan dimana untuk menghasilkan suatu pendapatan yang persenannya berdasarkan ketentuan yang telah ditentukan oleh perusahaan.

2. Modal eksternal, adalah segala sesuatu modal yang dimiliki perusahaan dan besarnya modal eksternal juga ditentukan oleh perusahaan

Dapat disimpulkan bahwa modal diartikan berasal dari semua transaksi atau kejadian yang terjadi pada badan usaha dan akan mempengaruhi kegiatan perusahaan pada periode tertentu yang dihitung dari nilai sisa atas aktiva dikurangi kewajiban (hutang). 
Menurut Endang Purwanti (2012 : 19) secara keseluruhan modal usaha terbagai menjadi tiga bagian yaitu :

1. Modal Investasi

Modal investasi merupakan jenis modal usaha yang harus dikeluarkan dan dipakai dalam jangka panjang. Modal usaha untuk investasi nilainya cukup besar karena dipakai untuk jangka panjang. Namun modal investasi akan menyusut dari tahun ke tahun bahkan bias dari bulan ke bulan.

2. Modal Kerja

Modal kerja adalah modal usaha yang diharuskan untuk membuat atau membeli barang dagangan. Modal kerja ini dapat dikeluarkan tiap bulan atau pada waktu-waktu tertentu.

3. Modal Opersioanal

Modal operasional adalah modal usaha yang harus dikeluarkan untuk membayar biaya operasi bulanan misalnya pembayaran gaji pegawai, listrik dan lainnya. berikut:

Menurut Endang Purwanti, indikator modal usaha adalah sebagai

1. Modal sebagai syarat untuk usaha

Modal usaha mutlak diperlukan untuk melakukan kegiatan usaha. Setiap usaha atau perusahan membutuhkan dana atau biaya untuk dapat beroperasi. Artinya tanpa modal usaha, setiap usaha akan mengalami kesulitan dalam melakukan proses usahanya, baik memproduksi barang-barang maupun melakukan transaksi jual-beli barang. Oleh karena itu diperlukan sejumlah dana sebagai dasar ukuran finansial atau usaha yang dijalankan. Kasmir ( 2009. 93)

2. Pemanfaatan modal tambahan

Bantuan modal yang diterima mutahiq dimanfaatkan untuk menjalankan usahanya sehingga volume atau omset penjualan dan keuntungan yang diperoleh bias meningkat.

3. Besar Modal

Modal adalah faktor usaha yang harus tersedia sebelum melakukan kegiatan. Besar kecilnya modal akan mempengaruhi perkembangan usaha dalam pencapaian pendapatan. Dan besar kecilnya modal yang dibutuhkan tergantung dari besar kecilnya usaha yang akan didirikan.

Berdasarkan teori dan indikaror modal usaha yang telah dibahas diatas, maka yang menjadi indikator modal usaha dalam penelitian ini adalah :

1. Besar Modal

2. Modal investasi

3. Modal kerja

4. Modal operasional

Wirausaha berasal dari kata wira yang artinya kesatria, pahlawan, penjual, unggul, gagah berani, dan kata usaha artinya adalah bekerja atau melakukan sesuatu. Dengan demikian, wirausaha dapat diartikan sebagai orang tangguh yang sedang melakukan sesuatu. Kewirausahaan lebih dikenal dengan istilah entrepreneur. Dewasa ini, wirausaha dikaitkan pada istilah bisnis, karena pada dasarnya kegiatan wirausaha sering kali disebut bisnis. Bisnis dalam hal ini diartikan segala aktivitas untuk mendapatkan keuntungan untuk dapat memperbaiki kualitas hidup. Untuk menampung seluruh aktivitas maka dibentuklah organisasi berupa perusahaan. Perusahaan tidak harus diartikan dalam 
arti besar, tapi bisa berawal dari usaha kecil yang ditampung dalam organisasi yang kecil, yang akhirnya akan berkembang menjadi organisasi yang besar.

Raymond W. Y. Kao dalam Saban Echdar menjelaskan, "Kewirausahaan sebagai suatu proses, yakni proses penciptaan sesuatu yang baru (kreasi baru) dan membuat sesuatu yang berbeda dari yang sudah ada (inovasi), tujuannya adalah tercapainya kesejahteraan individu dan nilai tambah bagi masyarakat. Sedangkan wirausaha mengacu pada orang yang melaksanakan proses penciptaan kesejahteraan atau kekayaan dan nilai tambah. Dengan kata lain, seorang wirausahawan adalah orang yang mampu menetaskan gagasan menjadi realita. Wirausaha merupakan pilihan yang tepat bagi individu yang tertantang untuk menciptakan kerja, bukan mencari kerja"

Minat secara umum dapat diartikan sebagai rasa tertarik yang ditunjukkan oleh seseorang kepada suatu objek. Minat menimbulkan keinginan untuk mengetahui dan mempelajari suatu objek tertentu dengan perasaan senang dan berniat untuk mewujudkannya sebagai pilihan hidup. Setiabudi dalam Muhammad Busro (2017. 247), mendefinisikan bahwa, "Minat adalah kecenderungan hati yang tinggi untuk mendapatkan informasi, pengetahuan, kecakapan, melalui usaha, atau pengalaman, minat yaitu perasaan tertarik atau ketertarikan pada suatu hal atau aktivitas tanpa ada yang menyuruh".

Dapat diketahui bahwa minat merupakan kesadaran seseorang yang dapat menimbulkan adanya keinginan suatu hal daripada hal lainnya dengan aktif melakukan kegiatan yang menjadi objek kesukaannya. Keinginan yang timbul dalam diri individu tersebut dinyatakan dengan suka atau tidak suka, terhadap suatu keinginan yang akan memuaskan kebutuhan. Minat merupakan salah satu hal yang ikut menentukan keberhasilan seseorang dalam segala bidang, baik studi, kerja dan kegiatan lain.

Minat wirausaha adalah gejala psikis untuk memusatkan perhatian dan berbuat sesuatu terhadap wirausaha itu dengan perasaan senang karena membawa manfaat bagi dirinya. Minat berwirausaha adalah keinginan, ketertarikan serta kesediaan untuk bekerja keras atau berkemauan keras untuk berdikari atau berusaha memenuhi kebutuhan hidupnya tanpa merasa takut dengan resiko yang akan terjadi, serta senantiasa belajar dari kegagalan yang dialami. Ketika kepuasan menurun maka minat juga akan menurun karena minat tidak bersifat permanen, tetapi bersifat sementara atau dapat berubah-ubah. Istilah wirausaha umumnya digunakan untuk menjelaskan orang yang bekerja mandiri, menjadi seorang wirausaha lebih dari sekedar pekerjaan atau karir.

Menurut pemaparan uraian di atas, dapat disimpulkan bahwa minat berwirausaha adalah suatu kecenderungan hati dalam diri subyek atau individu untuk tertarik menciptakan suatu usaha yang kemudian mengorganisir, mengatur, menanggung resiko dan mengembangkan usaha yang diciptakannya tersebut.

Minat berwirausaha tidak dibawa sejak lahir, namun berkembang sesuai dengan faktor-faktor yang mempengaruhinya. Faktor-faktor yang mempengaruhi minat berwirausaha meliputi karakteristik (yakni jenis kelamin dan usia), lingkungan (yakni lingkungan keluarga, lingkungan pendidikan, dan lingkungan masyarakat), kepribadian (yakni kesepahaman, berani mengambil resiko, kebutuhan berprestasi dan independen, evaluasi diri serta kepercayaan diri yang lebih) dan motif berwirausaha (yakni bekerja dan penyaluran ide kreatif).

Menurut Bandura dalam Saban Echdar, (2013. 20) jenis-jenis insentif yang diharapkan menjadi wirausaha, antara lain: 
a. "Insentif primer, seseorang menjadi wirausaha karena dapat memenuhi kebutuhan dasarnya seperti makanan dan perumahan.

b. Insentif token dan eknonomi, insentif ini paling banyak dilihat bentuknya yakni berwirausaha karena dapat memperbaiki kesejahteraan hidup atau kaya.

c. Insentif aktifitas, tidak suka bekerja pada orang lain karena merasa terkekang. Dengan menjadi wirausaha, dapat bebas beraktivitas tanpa harus ada tekanan dari atasan.

d. Insentif sosial, status dan pengaruh, jika berhasil menjadi wirausaha sukses, maka akan mendapat perhatian dari lingkungan sekitarnya. Pemberian status dari masyarakat juga membuatnya memiliki pengaruh terhadap orang lain.

e. Insentif terpenuhinya standar internal, pada orang tertentu memiliki kebutuhan berprestasi tinggi sangat cocok dengan kriteria wirausaha"

Manusia dalam menjalankan hidup pasti memiliki tujuan yang didorong oleh motivasi yang berasal dalam dirinya sendiri. Motivasi seseorang untuk berwirausaha menumbuhkan upaya untuk memulai bisnis sendiri yang akhirnya dapat menumbuhkan kerjasama antara orang lain dengan yang lainnya.

Saiman Leonardus menyatakan bahwa peristiwa yang mempercepat/memicu seseorang menjadi wirausahawan, antara lain:

1. "Kehilangan pekerjaan karena mengalami PHK dari tempat kerja

2. Memasuki usia pensiun, sehingga memiliki waktu luang yang lebih banyak

3. Sulitnya memperoleh pekerjaan - melamar pekerjaan di berbagai instansi yang selalu ditolak (karena memang sempitnya kesempatan kerja)

4. Telah mengikuti berbagai seminar, kursus, atau memperoleh mata kuliah kewirausahaan

5. Memperoleh sharing pengalaman dari wirausahawan atau famili yang telah berhasil atau memiliki bisnis sebelumnya". (Leonardus Saiman, 2009. 25)

Menurut Saiman Leonardus terdapat empat faktor yang mempengaruhi seseorang menjadi wirausaha, yaitu:

a. "Laba - Seseorang melakukan kegiatan wirausaha agar dapat menentukan berapa laba yang dikehendaki, keuntungan yang diterima, dan berapa yang akan dibayarkan kepada pihak lain atau pegawainya.

b. Kebebasan - Seseorang melakukan kegiatan wirausaha agar dapat bebas mengatur waktu, bebas dari supervisi, bebas aturan main yang menekan atau intervensi, serta bebas dari aturan budaya organisasi atau perusahaan.

c. Impian Personal - Seseorang melakukan kegiatan wirausaha agar bebas mencapai standar hidup yang diharapkan, lepas dari rutinitas kerja yang membosankan, karena harus mengikuti visi misi dan impian orang lain.

d. Kemandirian - Seseorang melakukan kegiatan wirausaha memiliki rasa bangga karena dapat mandiri dalam segala hal, seperti permodalan, mandiri dalam pengelolaan atau manajemen, mandiri dalam pengawasan, serta menjadi manajer terhadap dirinya sendiri”.( Leonardus Saiman, 2009. 26)

Dapat dikatakan bahwa faktor motivasi tersebut berupa keuntungan yang tidak akan didapat apabila bekerja disebuah industri atau bekerja dengan orang lain. Menurut Adi Sutanto dalam Aditya Dion Mahesa, "Faktor-faktor yang memotivasi seseorang untuk menjadi entrepreneur yaitu kebebasan dalam bekerja, keberhasilan diri yang dicapai, dan toleransi akan adanya resiko".

a. Kebebasan Dalam Bekerja

Beberapa entrepreneur menggunakan kebebasannya untuk menyusun kehidupan dan perilaku kerja pribadinya secara fleksibel. Kebebasan dalam 
bekerja adalah suatu nilai lebih bagi seorang entrepreneur. Pada dasarnya orang yang mempunyai jiwa kepemimpinan maupun memiliki inisiatif, akan lebih tertantang untuk melakukan suatu pekerjaan yang membebaskan segala inovasi dan kreativitasnya. Kebebasan dalam bekerja merupakan sebuah model kerja dimana seseorang melakukan pekerjaan untuk dirinya sendiri. Berangkat kerja tanpa terikat pada aturan atau jam kerja formal, atau tidak mendapatkan tekanan dari atasan. Dengan memiliki usaha sendiri, seorang entrepreneur mempunyai jam kerja yang bebas, pendapatan yang diperoleh juga lebih besar. Jika bisnis yang dijalankan sudah berjalan dengan baik tidak perlu setiap hari pergi ke kantor karena bisa didelegasikan kepada orang lain. Waktu bisa dibagi untuk aktifitas lain. Meski seorang entrepreneur memerlukan disiplin yang tinggi tetapi dengan memiliki usaha sendiri, dapat mengatur waktu sesuai keinginan sendiri tanpa diatur oleh orang lain.

b. Keberhasilan Diri Yang Dicapai

Ada dua ukuran tentang keberhasilan diri yang mendorong seseorang untuk berwirausaha. Ukuran pertama dianalogikan dengan harapan, dan ukuran kedua dianalogikan dengan hasil dari harapan tersebut. Keberhasilan diri sebagai seorang entrepreneur disini kemungkinan dari mendapatkan kesempatan-kesempatan yang diinginkan dan keuntungan pekerjaan atas pekerjaan yang telah dilakukan. Keberhasilan dalam berwirausaha didefinisikan sebagai pendorong keinginan seseorang untuk menjadi entrepreneur. Artinya, jika seseorang mencapai tujuan usaha yang diinginkan melalui prestasi, ia akan dianggap berhasil.

Lingkungan yang dinamis menyebabkan seorang entrepreneur menghadapi keharusan untuk menyesuaikan dan mengembangkan diri agar keberhasilan dapat dicapai. Seorang entrepreneur bukan saja mengikuti perubahan yang terjadi dalam dunia usaha tapi perlu berubah seseringkali dan dengan cepat memiliki pemikiran yang inovatif.

c. Toleransi Akan Resiko

Wirausaha dalam mengambil tindakan hendaknya tidak didasari oleh spekulasi, melainkan perhitungan yang matang. Ia berani mengambil resiko terhadap pekerjaannya karena sudah diperhitungkan. Pengambilan keputusan pelaku bisnis sebaiknya mempertimbangkan tingkat toleransi akan adanya resiko.

Menurut Purwanto dalam Muhammad Busro, terdapat dua faktor yang mempengaruhi tinggi rendahnya minat bekerja, yaitu faktor internal dan faktor eksternal. Faktor internal adalah faktor yang berasal dari dalam diri seseorang, seperti:

1. "Pembawaan,

2. Kebiasaan dan

3. Ekspresi diri.

Sementara faktor eksternal adalah faktor-faktor yang berasal dari luar diri seseorang atau faktor lingkungan, baik dari:

1. Lingkungan keluarga,

2. Tetangga, maupun

3. Lingkungan sosial". Muhammad Busro, (2017. 256)

Menurut Meckel dalam Muhammad Busro (2017. 263) membedakan minat menjadi dua, yaitu: 
1. "Minat spontan, yaitu kegiatan yang dilakukan atas kemauan, inisiatif pribadi sendiri tanpa terpengaruh dari pihak luar atau pihak lain.

2. Minat terpola, ialah kegiatan yang dilakukan sebagai hasil atau akibat pengaruh langsung dan disengaja melalui serangkaian tindakan dan program yang terpola, terutama kegiatan bekerja di tempat organisasi atau perusahaan".

Ada tiga faktor yang memotivasi seseorang berkeinginan menjadi entrepreneur yaitu

1. Seorang entrepreneur menghargai kebebasan dalam karir kewirausahaan, seperti bekeja dengan cara sendiri, memungut laba, mengatur jadwal sendiri.

2. Keberhasilan diri yang dicapai salah satu wakil motivasi untuk menjadi entrepreneur karena percaya bahwa orang-orang akan termotivasi untuk menjadi entrepreneur.

3. Toleransi akan resiko, dalam pengambilan keputusan seorang entrepreneur sebaiknya mempertimbangkan tingkat toleransi akan adanya resiko.

Berdasarkan teori dan indikator yang telah dibahas diatas, maka yang menjadi indikator variabel minat berwirausaha dalam penelitian ini adalah :

1. Percaya diri

2. Berorientasi pada masa depan

3. Tanggung jawab

4. Menyukai tantangan

5. Kemampuan melihat peluang

6. Memiliki komitmen

7. Tidak suka diatur

8. Pendapatan lebih besar

Untuk memberikan arah bagi penelitian ini maka diajukan suatu hipotesis. Hipotesis adalah suatu pernyataan atau dugaan yang masih lemah kebenaranya dan perlu dibuktikan atau dugaan yang sifatnya semantara. Adapun hipotesis yang dapat diajukan dari kerangka pikiran teoritis tersebut adalah sebagai berikut :

$\mathrm{H}_{1}$ : Motivasi secara parsial berpengaruh positif dan signifikan terhadap minat masyarakat berwirausaha.

$\mathrm{H}_{2}$ : Modal Usaha secara parsial berpengaruh positif dan signifikan terhadap minat masyarakat berwirausaha.

$\mathrm{H}_{3}$ : Motivasi dan Modal Usaha secara simultan berpengaruh positif dan signifikan terhadap minat masyarakat berwirausaha.

\section{METODOLOGI PENELITIAN}

Penelitian ini dilakukan pada bulan Pebruari - Maret 2021 di objek penelitian Pasar Komplek MMTC, Kota Medan Sumatera Utara. Penelitian ini menggunakan metode kuantitatif dengan pendekatan asosiatif. Pendekatan asosiatif merupakan pendekatan yang bermaksud untuk menjelaskan hubungan kausal dan pengaruh antara variabel-variabel melalui pengujian hipotesis. Penelitian ini menggunakan dua jenis variabel, yaitu Motivasi $\left(\mathrm{X}_{1}\right)$ dan Modal kerja $\left(\mathrm{X}_{2}\right)$ sebagai independen, Minat Berwirausaha $(\mathrm{Y})$ sebagai variabel dependen.

Populasi dalam penelitian ini adalah wirausahawan di Pasar Komplek MMTC, Kota Medan yang telah menjalankan usahanya lebih dari satu tahun. Adapun jumlah populasi dalam penelitian ini ialah sejumlah 100 wirausahawan. Pengumpulan data dalam penelitian ini dilakukan melalui wawancara dan 
kuesioner dengan skala pengukuran Likert. Jawaban pertanyaan yang diajukan yaitu sangat setuju (SS) dengan skor 5, setuju (S) skor 4, kurang setuju (KS) skor 3, tidak setuju (TS) skor 2, dan sangat tidak setuju (STS) dengan skor 1. Sementara yang digunakan adalah data primer dan data sekunder.

Agar suatu data yang dikumpulkan dapat bermanfaat, maka harus diolah dan dianalisis terlebih dahulu sehingga dapat dijadikan dasar pengambilan keputusan dengan menggunakan uji validitas dan reliabilitas.

Uji validitas digunakan untuk mengukur sah atau valid tidaknya suatu kuesioner. Suatu kuesioner dikatakan valid jika pertanyaan atau pernyataan pada kuesioner mampu untuk mengungkapkan sesuatu yang akan diukur oleh kuesioner tersebut. Jika $r_{\text {hitung }}>r_{\text {tabel }}$ dan bernilai positif maka butir atau pertanyaan atau indikator tersebut dinyatakan valid. Tinggi rendahnya validitas instrumen menunjukkan sejauh mana data yang terkumpul tidak menyimpang dari gambaran tentang variabel yang dimaksud.

Uji reliabiltas adalah suatu indek yang menunjukkan sejauh mana hasil suatu penelitian pengukur dapat dipercaya. Hasil pengukuran dapat dipercaya apabila digunakan dalam beberapa kali pengukuran terhadap kelompok subjek yang sama diperoleh hasil yang relatif sama, selama aspek yang diukur dalam diri subjek tidak berubah. Suatu kuesioner dikatakan reliabel atau handal jika jawaban seseorang terhadap pernyataan adalah konsisten atau stabil dari waktu ke waktu.

Penelitian ini menggunakan alat analisis regresi untuk menemukan atau mengetahui pengaruh variabel bebas terhadap variabel terikat dengan menggunakan program komputer SPSS. Analisis regresi adalah studi mengenai ketergantungan variabel dependen dengan satu atau lebih variabel independen. Regresi dilakukan untuk mengetahui sejauh mana variabel independen mempengaruhi variabel dependen. Dalam penelitian ini yang menjadi variabel dependen adalah minat berwirausaha, sedangkan yang menjadi variabel independen adalah motivasi dan modal usaha.

Uji statistik $t$ pada dasarnya menunjukkan seberapa jauh pengaruh satu variabel independen secara parsial dalam menerangkan variabel dependen denagn Kriteria pengujian :

1. Jika $\mathrm{t}_{\text {hitung }}>\mathrm{t}_{\text {tabel}}$, maka $\mathrm{H}_{0}$ ditolak yang berarti ada pengaruh antara masing-masing variabel independen terhadap variabel dependen. Dan sebaliknya, jika $t_{\text {hitung }}<\mathrm{t}_{\text {tabel }}$, maka $\mathrm{H}_{0}$ diterima berarti tidak ada pengaruh antara masing-masing variabel independen terhadap variabel dependen.

2. jika nilai signifikansi yang diperoleh $<0,05$, berarti terdapat pengaruh yang signifikan antara variabel independen terhadap variabel dependen.

Uji statistik $F$ pada dasarnya menunjukkan apakah semua variabel independen secara simultan mempunyai pengaruh terhadap variabel dependen dengan kriteria pengujian : Jika F hitung $>\mathrm{F}$ tabel, maka H0 ditolak yang berarti ada pengaruh secara simultan variabel independen terhadap variabel dependen, dan sebaliknya jika $\mathrm{F}$ hitung $<\mathrm{F}$ tabel, maka H0 diterima yang berarti tidak terdapat pengaruh secara simultan.

\section{HASIL PENELITIAN}

Pasar Komplek Medan Metropolitan Trade Centre (MMTC) terletak di Jalan Willem Iskandar, Desa Kenangan Baru, Kecamatan Percut Sei Tuan, Deli Serdang. Pasar tradisional modern yang dibangun di atas lahan sekitar 7 hektar ini dapat mengakomodasi para pedagang dari Kabupaten Deli Serdang maupun Kota 
Medan. Selain mengakomodasi para pedagang, Pasaraya tersebut juga dapat memenuhi segala kebutuhan masyarakat yang bermukim di Kota Medan dan Deli Serdang, dikarenakan lokasi pasaraya tersebut yang sangat strategis. Pasar ini diproyeksikan sebagai pusat belanja, busana, elektronik, kuliner hingga hiburan di tengah masyarakat.

Berdasarkan hasil jawaban responden tentang jenis kelamin dapat disajikan pada tabel berikut:

Tabel 1. Karakteristik Responden Berdasarkan Jenis Kelamin

\begin{tabular}{|c|c|c|}
\hline Jenis Kelamin & Jumlah & Persentase (\%) \\
\hline Laki-laki & 35 & $35 \%$ \\
\hline Perempuan & 65 & $65 \%$ \\
\hline Total & 100 & $100 \%$ \\
\hline
\end{tabular}

Sumber: Data Primer diolah

Berdasarkan data Tabel 4.1 dapat diketahui bahwa responden yang berjenis kelamin laki-laki sebanyak 35 orang dengan persentase sebesar 35\%, sedangkan perempuan sebanyak 65 orang dengan persentase sebesar 65\%. Dapat disimpulkan dari data sampel yang didapat dengan penyebaran 100 kuesioner bahwa responden dalam penyebaran ini lebih besar perempuan (65\%) yang berwirausaha dibandingkan laki-laki (35\%).

Pengujian validitas dilakukan memakai Pearson Correlation, dihitung dengan menggunakan bantuan komputer program SPSS versi 22 . Untuk mengetahui apakah variabel yang diuji tersebut valid atau tidak, diketahui dengan cara membandingkan nilai $r$ hitung dengan $r$ tabel untuk degree of freedom $(\mathrm{df})=$ $\mathrm{n}-2$, dalam hal ini $\mathrm{n}=100$ pada taraf signifikansi $5 \%$. Maka df dalam penelitian ini dengan sampel sebanyak $100-2=98$ dan $r$ tabel sebesar 0,2 .

Hasil uji validitas melalui program SPSS versi 22 untuk indikator variabel motivasi $\left(X_{1}\right) r_{\text {hitung }}$ diperoleh : $X_{1.1}(0,938), X_{1.2}(0,880), X_{1.3}(0,913), X_{1.4}$ $(0,887)$. Sesuai dengan kriteria pengujian, jika $r_{\text {hitung }}>r_{\text {tabel }}(0,2)$, maka intrumen pengukuran indikator variabel motivasi $\left(\mathrm{X}_{1}\right)$ dinyatakan valid. Hasil uji validitas melalui program SPSS versi 22 untuk indikator variabel modal usaha $\left(\mathrm{X}_{2}\right) \mathrm{r}_{\text {hitung }}$ diperoleh : $X_{2.1}(0,633), X_{2.2}(0,735), X_{2.3}(0,745), X_{2.4}(0,779)$. Sesuai dengan kriteria pengujian, jika $r_{\text {hitung }}>r_{\text {tabel }}(0,2)$, maka intrumen pengukuran indikator variabel modal usaha $\left(\mathrm{X}_{2}\right)$ dinyatakan valid. Hasil uji validitas melalui program SPSS versi 22 untuk indikator variabel minat berwirausaha $(\mathrm{Y}) \mathrm{r}_{\text {hitung }}$ diperoleh : $Y_{1.1}(0,726), Y_{1.2}(0,652), Y_{1.3}(0,751), Y_{1.4}(0,786), Y_{1.5}(0,747), Y_{1.6}(0,593)$, $Y_{1.7}(0,855), Y_{1.8}(0,734)$. Sesuai dengan kriteria pengujian, jika $r_{\text {hitung }}>r_{\text {tabel }}(0,2)$, maka intrumen pengukuran indikator variabel minat berwirausaha $(\mathrm{Y})$ dinyatakan valid.

Pengujian reliabilitas setiap variabel dilakukan dengan melihat nilai Cronbarch Alpha yang diperoleh. Data yang diperoleh dapat dikatakan reliabel apabila nilai Cronbarch Alpha $\geq 0,60$ (Ghozali, 2009). Hasil pengujian untuk variabel motivasi $\left(\mathrm{X}_{1}\right)$ Cronbach's Alpha sebesar 0,923, variable modal usaha $\left(\mathrm{X}_{2}\right)$ Cronbach's Alpha sebesar 0,694, dan untuk variabel minat berwirausaha $(Y)$ Cronbach's Alpha sebesar 0,875. Dengan demikian, disimpulkan bahwa seluruh pernyataan dalam indikator variabel adalah reliabel.

Analisis regresi linier berganda digunakan untuk menguji kekuatan pengaruh kebebasan dalam bekerja, keberhasilan diri yang dicapai, dan toleransi akan resiko. Analisis regresi linier berganda dilakukan dengan rumus : 
Tabel 2. Hasil Analisis Regresi Linear Berganda Coefficients $^{\mathrm{a}}$

\begin{tabular}{|c|c|c|c|c|c|c|}
\hline \multirow{2}{*}{\multicolumn{2}{|c|}{ Model }} & \multicolumn{2}{|c|}{ Unstandardized Coefficients } & $\begin{array}{c}\text { Standardized } \\
\text { Coefficients }\end{array}$ & \multirow[b]{2}{*}{$\mathrm{t}$} & \multirow[b]{2}{*}{ Sig. } \\
\hline & & $\mathrm{B}$ & Std. Error & Beta & & \\
\hline \multirow[t]{3}{*}{1} & (Constant) & 30,791 & 3,474 & & 8,864 & ,000 \\
\hline & Motivasi & ,386 & ,081 & ,440 & 4,782 & ,000 \\
\hline & Modal Usaha &,- 194 & , 191 &,- 094 & $-1,016$ & ,312 \\
\hline
\end{tabular}

a. Dependent Variable: Minat Berwirausaha

Sumber: Data Primer diolah

Apabila memperhatikan model regresi dan hasil regresi linear berganda maka didapat persamaan variabel-variabel yang mempengaruhi minat wirausahawan yang berwirausaha sebagai berikut :

$$
Y=30,791+0,386\left(X_{1}\right)-0,194\left(X_{2}\right)+e
$$

Nilai konstanta (a) sebesar 30,791 yang berarti bahwa jika tidak ada perubahan pada variabel independen yang terdiri dari variabel motivasi dan modal usaha yang mempengaruhi minat berwirausaha, maka minat berwirausaha akan mempunyai nilai sebesar 30,791.

Variabel motivasi $\left(b_{1}\right)$ mempunyai pengaruh yang positif terhadap minat berwirausaha, dengan koefisien regresi sebesar 0,386 yang artinya apabila variabel motivasi meningkat, maka minat berwirausaha akan meningkat juga sebesar 0,386 satuan dengan asumsi bahwa variabel lain dalam kondisi konstan. Jika variabel motivasi semakin meningkat maka akan mengakibatkan minat berwirausaha akan semakin meningkat dan sebaliknya sebaliknya.

Variabel modal usaha $\left(b_{2}\right)$ mempunyai pengaruh yang negatif terhadap minat berwirausaha, dengan koefisien regresi sebesar - 0,194 yang artinya apabila variable modal usaha meningkat, maka minat berwirausaha akan menurun sebesar - 0,194 satuan dengan asumsi bahwa variabel lain dalam kondisi konstan. Dengan adanya pengaruh yang negatif ini, berarti bahwa antara variabel modal usaha dan minat berwirausaha menunjukkan hubungan yang tidak searah di MMCT Medan. Jika variabel modal usaha semakin meningkat mengakibatkan minat berwirausaha akan semakin menurun dan sebaliknya.

Pengujian hipotesis dilakukan untuk melakukan pembuktian hipotesis yang didasarkan pada penelitian yang sudah ada. Pengujian ini meliputi uji t, uji F dan koefisien determinan.

\section{Tabel 3. Uji Parsial Variabel Motivasi $\left(X_{1}\right)$ Terhadap Minat Berwirausaha}

(Y)

Coefficients $^{\mathrm{a}}$

\begin{tabular}{|c|c|c|c|c|c|c|}
\hline \multirow{2}{*}{\multicolumn{2}{|c|}{ Model }} & \multicolumn{2}{|c|}{ Unstandardized Coefficients } & $\begin{array}{l}\text { Standardized } \\
\text { Coefficients }\end{array}$ & \multirow[b]{2}{*}{$\mathrm{t}$} & \multirow[b]{2}{*}{ Sig. } \\
\hline & & $\mathrm{B}$ & Std. Error & Beta & & \\
\hline \multirow[t]{2}{*}{1} & (Constant) & 27,512 & 1,286 & & 21,396 & ,000 \\
\hline & Motivasi & ,375 & ,080 & ,428 & 4,688 &, 000 \\
\hline
\end{tabular}

a. Dependent Variable: Minat Berwirausaha

Sumber: Data Primer diolah

Berdasarkan kriteria pengujian $t_{\text {tabel}}$, nilai $t$ hitung yang dihasilkan pada variabel Motivasi $(\mathrm{X} 1)=4,688>\mathrm{t}$ tabel $(\alpha=0,05 / 2 ; \mathrm{n}-\mathrm{k}-1)=1,985$. Berarti 
variabel Motivasi (X1) berpengaruh positif terhadap Minat berwirausaha. Disimpulkan, H0 ditolak dan Ha diterima.

Berdasarkan kriteria pengujian nilai signifikansi, diperoleh nilai sig. $0,000<$ 0,05 , yang berarti terdapat pengaruh yang signifikan antara variable Motivasi terhadap Minat berwirausaha. Dengan demikian, disimpulkan bahwa variabel Motivasi $\left(\mathrm{X}_{1}\right)$ berpengaruh positif dan signifikan terhadap variabel Minat berwirausaha $(\mathrm{Y})$.

\section{Tabel 4. Uji Parsial Variabel Modal Usaha (X2) Terhadap Minat \\ Berwirausaha (Y) Coefficients $^{\mathrm{a}}$}

\begin{tabular}{|c|c|c|c|c|c|}
\hline \multirow[b]{2}{*}{ Model } & \multicolumn{2}{|c|}{ Unstandardized Coefficients } & $\begin{array}{c}\text { Standardized } \\
\text { Coefficients }\end{array}$ & \multirow[b]{2}{*}{$\mathrm{t}$} & \multirow[b]{2}{*}{ Sig. } \\
\hline & B & Std. Error & Beta & & \\
\hline $1 \quad$ (Constant) & 34,712 & 3,733 & & 9,298 & ,000 \\
\hline Modal Usaha &,- 073 & ,209 &,- 035 &,- 350 & ,727 \\
\hline
\end{tabular}

a. Dependent Variable: Minat Berwirausaha

Sumber: Data Primer diolah

Berdasarkan kriteria pengujian $\mathrm{t}_{\text {tabel }}$, nilai $\mathrm{t}$ hitung yang dihasilkan pada variabel Modal Usaha $\left(\mathrm{X}_{2}\right)=-0,350<\mathrm{t}$ tabel $(\alpha=0,05 / 2 ; \mathrm{n}-\mathrm{k}-1)=1,985$. Hal ini berarti variabel modal usaha $\left(\mathrm{X}_{2}\right)$ berpengaruh negatif terhadap Minat berwirausaha. Sehingga disimpulkan, $\mathrm{H} 0$ diterima dan Ha ditolak.

Berdasarkan kriteria pengujian nilai signifikansi, diperoleh nilai sig.0,727 $>0,05$, yang berarti tidak terdapat pengaruh antara variabel modal usaha terhadap Minat berwirausaha. Sehingga, disimpulkan bahwa variabel modal usaha $\left(\mathrm{X}_{2}\right)$ tidak berpengaruh terhadap variabel Minat berwirausaha (Y).

Pengujian Simultan (F) ini bertujuan untuk mengetahui sejauh mana variabel independen yang digunakan mampu menjelaskan variabel dependen. Dalam penelitian ini motivasi $\left(\mathrm{X}_{1}\right)$ dan modal usaha $\left(\mathrm{X}_{2}\right)$ secara stimultan terhadap variabel minat berwirausaha $(\mathrm{Y})$. Hasil yang didapat adalah:

Tabel 5. Uji Simultan (F)

ANOVA $^{\mathrm{a}}$

\begin{tabular}{|ll|r|r|r|r|r|}
\hline Model & & Sum of Squares & df & Mean Square & F & Sig. \\
\hline 1 & Regression & 161,895 & 2 & 80,947 & 11,508 &, $000^{\mathrm{b}}$ \\
& Residual & 682,295 & 97 & 7,034 & & \\
& Total & 844,190 & 99 & & & \\
\end{tabular}

a. Dependent Variable: Minat Berwirausaha

b. Predictors: (Constant), Motivasi, Modal Usaha

Sumber: Data Primer diolah

Berdasarkan Tabel 4.18 didapat nilai $\mathrm{F}$ hitung sebesar 11,508 $>\mathrm{F}$ tabel $(\alpha=$ $\mathrm{k} ; \mathrm{n}-\mathrm{k})=2,70$ dengan $\mathrm{F}$ sig. 0,000 dimana $\mathrm{F}$ sig. 0,000 < 0,05 maka H0 ditolak. Dapat diartikan bahwa motivasi $\left(\mathrm{X}_{1}\right)$ dan modal usaha $\left(\mathrm{X}_{2}\right)$ beperngaruh positif dan signifikan secara simultan terhadap minat berwirausaha $(\mathrm{Y})$.

\section{PEMBAHASAN}

Hasil penelitian menemukan bahwa variable motivasi berpengaruh signifikan positif terhadap minat berwirausaha. Hasil ini sesuai dengan hipotesis 
awal penelitian yang menyatakan bahwa motivasi berpengaruh positif dan signifikan terhadap minat berwirausaha". Ini menggambarkan bahwa semakin tingginya motivasi yang dimiliki, maka akan semakin tinggi pula minat yang timbul dalam berwirausaha.

Hasil penelitian menunjukkan bahwa variable modal usaha tidak berpengaruh terhadap minat berwirausaha. Hasil yang didapat ini tidak sesuai dengan hipotesis awal yang menyatakan bahwa modal usaha berpengaruh positif dan signifikan terhadap minat berwirausaha. Hasil ini menggambarkan bahwa semakin yang dicapai dalam bekerjaesar modal usaha, maka tidak akan semakin menumbuhkan minat berwirausaha.

Wirausahawan dalam mengambil tindakan atas usaha yang dikelola tidak didasari oleh spekulasi, melainkan perhitungan yang matang. Ini menunjukkan bahwa seorang wirausahawan berani mengambil resiko terhadap pekerjaannya karena sudah diperhitungkan. Pengambilan keputusan pelaku bisnis dalam usahanya juga mempertimbangkan tingkat toleransi akan adanya resiko usaha. Menurut Yuyun Wirasasmita, seorang wirausaha yang berani menanggung risiko adalah orang yang selalu ingin jadi pemenang dan memenangkan sesuatu hal dengan cara yang baik

Berdasarkan hasil Uji F (Simultan) diperoleh kesimpulan nilai signifikan 0,000 pada taraf signifikansi sebesar $0,05(0,000<0,05)$. Jadi dari data yang diperoleh nilai sig. $(0,000<0,05)$, maka $\mathrm{H} 0$ ditolak dan Ha diterima. Sehingga variabel independen (motivasi dan modal usaha) secara bersama-sama berpengaruh positif dan signifikan terhadap Minat Berwirausaha.

\section{KESIMPULAN}

Berdasarkan hasil penelitian seperti yang telah diuraikan pada bab sebelumnya, maka dapat ditarik beberapa kesimpulan yaitu :

1. Berdasarkan hasil Uji t, variable motivasi secara parsial berpengaruh positif dan signifikan terhadap minat berwirausaha di Pasar Komplek MMTC, Kota Medan.

2. Berdasarkan hasil Uji t, variable modal usaha secara parsial tidak berpengaruh terhadap minat berwirausaha di Pasar Komplek MMTC, Kota Medan.

3. Berdasarkan hasil Uji F, variabel motivasi dan modal usaha secara simultan berpengaruh positif signifikan terhadap minat berwirausaha di Pasar Komplek MMTC, Kota Medan.

Berdasarkan hasil pembahasan dan kesimpulan di atas dapat diberikan saran sebagai berikut :

1. Dari hasil penelitian, variabel-variabel bebas memiliki pengaruh positif signifikan terhadap variabel minat berwirausaha, maka disarankan agar pemerintah setempat untuk lebih berusaha mengenalkan budaya berwirausaha di kalangan masyarakat. Sehingga diharapkan semakin hari semakin banyak lapangan kerja yang tercipta dan semakin mengikis tingkat pengangguran di masyarakat.

2. Dengan melihat hasil yang diperoleh dari penelitian melalui variabel motivasi, disarankan agar para wirausahawan dapat memberikan motivasi di kalangan masyarakat agar semakin banyak masyarakat yang termotivasi untuk berwirausaha setelah melihat keberhasilan yang dicapai. 
3. Peneliti yang akan datang disarankan untuk menggunakan variabel lain yang belum pernah diteliti sebelumnya. Agar semakin banyak variasi penelitian yang tercipta dengan tema berwirausaha.

\section{DAFTAR PUSTAKA}

Ardana, I Komang dkk. 2012. "Manajemen Sumber Daya Manusia". Yogyakarta: GRAHA ILMU.

Busro, Muhammad. 2017. "Manajemen Sumber Daya Manusia". Yogyakarta: EXPERT, 2017.

Echdar, Saban. 2013. "Manajemen Entrepreneurship - Kiat Sukses Menjadi Wirausaha". Yogyakarta: CV ANDI OFFSET.

Edison, Emron dkk. 2017. “Manajemen Sumber Daya Manusia: Strategi Dan Perubahan Dalam Rangka Meningkatkan Kinerja Pegawai Dan Organisasi”. Bandung: ALFABETA, cv.

Hamali, Ari Yusuf dan Eka Sari Budihastuti. 2017. "Pemahaman Kewirausahaan: Srategi Mengubah Pola Pikir "Orang Kantoran" Menuju Pola "Wirausahawan" Sukses". Depok: KENCANA

Kasali, Rhenald dkk. 2010. "Modul Kewirausahaan: Untuk Program Strata 1". Jakarta: PT Mizan Publika.

Mahesa, Aditya Dion. 2012. "Analisis Faktor Motivasi Yang Mempengaruhi Minat Berwirausaha”. Skripsi. Universitas Diponegoro Semarang.

Noor, Juliansyah. 2013. "Penelitian Ilmu Manajemen Tinjauan Filosofis Dan Praktis". Jakarta: KENCANA.

Priansa, Donni Juni. 2016. "Perencanaan Dan Pengembangan Sumber Daya Manusia". Bandung: ALFABETA, cv.

Saiman, Leonardus. 2009. "Kewirausahaan: Teori, Praktik, Dan Kasus-Kasus". Jakarta: Salemba Empat.

Sinaga, Dearlina. 2016. "Kewirausahaan: Pedoman Untuk Kalangan Praktisi Dan Mahasiswa". Yogyakarta: EKUILIBRIA

Winardi J. 2008. "Motivasi Dan Pemotivasian Dalam Manajemen". Jakarta: PT Raja Grafindo Persada.

Yuliardi, Ricki dan Zuli Nuraeni. 2017. "Stastistika Penelitian: Plus Tutorial SPSS". Yogyakarta: Innosain. 